OPEN ACCESS

Edited by:

Vida Abedi,

Geisinger Health System,

United States

Reviewed by:

Shokoufeh Shahrabi Farahani, University of Tennessee Health Science Center, United States Farimah Salami,

St. Jude Children's Research Hospital, United States

*Correspondence:

Nicola Luigi Bragazzi

robertobragazzi@gmail.com

Specialty section: This article was submitted to Nutritional Immunology, a section of the journal Frontiers in Immunology

Received: 15 July 2017 Accepted: 30 August 2017 Published: 27 November 2017

Citation:

Adawi M, Watad A, Brown S, Aazza K, Aazza H, Zouhir M, Sharif K, Ghanayem K, Farah R, Mahagna H, Fiordoro S, Sukkar SG, Bragazzi NL and Mahroum N (2017)

Ramadan Fasting Exerts Immunomodulatory Effects: Insights from a Systematic Review.

Front. Immunol. 8:1144. doi: 10.3389/fimmu.2017.01144

\section{Ramadan Fasting Exerts Immunomodulatory Effects: Insights from a Systematic Review}

\author{
Mohammad Adawi', Abdulla Watad ${ }^{2,3}$, Stav Brown ${ }^{3}, K_{\text {Khadija Aazza }}^{4}$, Hicham Aazza ${ }^{5}$, \\ Mohamed Zouhir ${ }^{5}$, Kassem Sharif ${ }^{2,3}$, Khaled Ghanayem ${ }^{3}$, Raymond Farah ${ }^{6}$, \\ Hussein Mahagna ${ }^{2,3}$, Stefano Fiordoro ${ }^{7}$, Samir Giuseppe Sukkar ${ }^{8}$, Nicola Luigi Bragazzi ${ }^{9 *}$ \\ and Naim Mahroum ${ }^{2,3}$ \\ 'Padeh and Ziv Hospitals, Bar-llan Faculty of Medicine, Zefat, Israel, '2Department of Medicine 'B', The Zabludowicz Center \\ for Autoimmune Diseases, Sheba Medical Center, Tel-Hashomer, Israel, ${ }^{3}$ Sackler Faculty of Medicine, Tel-Aviv University, \\ Tel-Aviv, Israel, ${ }^{4}$ Faculty of Sciences Dhar Mahraz, Sidi Mohamed Ben Abdellah University, Fez, Morocco, ${ }^{5}$ Faculty of \\ Literature and Humanistic Studies, Sidi Mohamed Ben Abdellah University, Fez, Morocco, ${ }^{6}$ Department of Internal Medicine, \\ Ziv Medical Center, Safed, Israel, ${ }^{7}$ Immunology Service, Ospedale Policlinico San Martino, Genoa, Italy, ${ }^{8}$ Clinical Nutrition \\ Unit, Ospedale Policlinico San Martino, Genoa, Italy, ${ }^{9}$ Department of Health Sciences (DISSAL), School of Public Health, \\ University of Genoa, Genoa, Italy
}

Ramadan is the ninth month of the Islamic lunar calendar and is observed by Muslims as a month of fasting. All Muslim adults are expected to fast; nevertheless certain subgroups, including sick, frail subjects, and pregnant women, among others, are exempted. Ramadan fasting has been shown to impact on body systems in different manners. The influence of Ramadan fasting on immune system regulation remains elusive; however, immune system changes, such as the modulation of body response to various infectious, stressful, and other harmful events, are of great interest during fasting. In this paper, we performed an extensive systematic literature review of different scholarly databases (ISI/Web of Science, Scopus, PubMed,/MEDLINE, Google Scholar, Directory of Open Access Journals, EbscoHOST, Scirus, Science Direct, the Cochrane Library, and ProQuest), using the following key words: "fasting," "Ramadan," "Islam," and "immunity." Conclusions drawn from these findings included: (1) Ramadan fasting has been shown to only mildly influence the immune system and the alterations induced are transient, returning to basal pre-Ramadan status shortly afterward. (2) Ramadan fasting during the second trimester of pregnancy was shown to be safe and did not result in negative fetal outcomes, or maternal oxidative status alterations. (3) In cardiac patients, Ramadan fasting can have beneficial effects including lipid profile improvement and alleviation of oxidative stress. (4) In asthmatic patients as well as in patients with human immunodeficiency virus/acquired immunodeficiency syndrome and autoimmune disorders, fasting was safe. (5) In psychiatric patients, such as those suffering from schizophrenia, fasting could increase immunologic markers. (6) Fasting Muslim athletes who maintain intensive training schedule during Ramadan showed fluctuations of immunologic markers.

Keywords: Ramadan, fasting, immune system, autoimmunity, antibodies 


\section{INTRODUCTION}

Ramadan, the ninth month of the Islamic lunar calendar, is observed by approximately 1.8 billion Muslims worldwide as a month of fasting and as one of the five pillars of Islam, along with testimony of faith, charity, pilgrimage, and daily prayer. It is believed that the revelation of the Qu'ran to Prophet Muhammad occurred during this month.

During daylight hours, Muslims abstain from eating any food, drinking any liquid, and other physical needs such as smoking and sexual intercourse. Furthermore, Ramadan has a strong ethical and spiritual dimension, in that it is a time to purify the soul and to gain proximity to God ("Allah") through reflection and supplication. While Muslims fast from dawn until sunset, food and drinks are allowed before dawn and after sunset (these meals are called Suhoor and Iftar, respectively) (1). The month of Ramadan lasts 29-30 days based on the witnessing of the small sliver of the crescent moon. The duration of the month varies upon the time of year and regional latitudes. Mean fasting duration is usually $13 \mathrm{~h}$, whereas in some regions it can extend to $18 \mathrm{~h}(1)$.

All Muslim adults are expected to fast; nevertheless, there exist dispensations for certain subsets of the Islamic community including pregnant, nursing or menstruating women, travelers, ill people, and the very young or the very old individuals.

As Ramadan fasting influences different body systems, of great interest is the influence of fasting on the immune system, which plays a critical role in regulating and maintaining body response to stressful and harmful events. This influence may shed light on immune status of fasting people. The clinical relevance of such topic stems from the fact that, in the world of globalization, any physician could face the issue of managing patients who choose to fast Ramadan and monitoring their immune status $(2,3)$. However, no guidelines or protocols exist that provide guidance toward a patient-tailored approach.

The purpose of this review was to fill this gap in knowledge, providing an insight on the possible influence of Ramadan fasting on the immune system.

\section{MATERIALS AND METHODS}

A systematic review according to the "Preferred Reporting Items for Systematic Reviews and Meta-Analyses" guidelines was performed by searching different databases, including ISI/Web of Science, Scopus, PubMed/MEDLINE, Directory of Open Access Journals, EbscoHOST, Scirus, Science Direct, the Cochrane Library and ProQuest. Search was carried out using a string made up of combination of key words including "Islam," "Ramadan," "fasting," and "immunity."

Gray literature was also manually searched via Google Scholar. Review articles or research manuscripts not pertinent with the aim of this systematic review were excluded, while all the other research articles (including editorials, letters, case reports) were retained if containing sufficient quantitative details. Neither time nor language filters were applied.

Review Manager version 5.3 (RevMan5.3, Cochrane) was used for handling all the processes of the present systematic review.

For further details, the reader is referred to Table 1 and Figure 1 .

TABLE 1 | Search strategy details.

\begin{tabular}{ll}
\hline Search strategy item & Search strategy details \\
\hline Used keywords & $\begin{array}{l}\text { ("Ramadan fast" OR "Ramadan fasting" OR "Ramadan month") AND (immune OR immunity OR immunologic OR } \\
\text { lymphocyte OR chemokine OR interleukin OR C-reactive protein OR CRP OR neutrophils OR "Oxidative stress" OR } \\
\text { "Oxidative burst" OR inflammatory OR inflammation OR immunoglobulin OR autoimmune OR "lipid peroxidation" OR } \\
\text { homocysteine OR malondialdehyde OR MDA OR glutathione OR GSH) }\end{array}$ \\
\hline Searched databases & $\begin{array}{l}\text { PubMed/MEDLINE, Scirus, Scopus, Directory of Open Access Journals, Google Scholar, ISI/Web of Science } \\
\text { Inclusion criteria }\end{array}$ \\
$\begin{array}{ll}\text { P: muslim subjects } \\
\text { C: subjects willing to fast during the month of Ramadan }\end{array}$ \\
$\begin{array}{ll}\text { O: impact of Ramadan fasting on immune system } \\
\text { S: original article }\end{array}$
\end{tabular}

Exclusion criteria Studies not reporting the impact of Ramadan fasting on immune system

Letter to editor, editorial, expert opinion, commentary not containing sufficient quantitative details, review article

\begin{tabular}{ll}
\hline Time filter & None applied (from inception) \\
\hline Language filter & None applied (in any language) \\
\hline Target journals & Allergologia et immunopathologia; Annals of Nutrition and Metabolism; Applied Physiology, Nutrition, and Metabolism; \\
& Asian Journal of Sports Medicine; Blood Pressure; European Journal of Nutrition; European Journal of Pediatrics; \\
& Indian Journal of Gastroenterology; International Journal of Pharmaceutical Science Invention; International Journal \\
& of Sport Nutrition and Exercise Metabolism; Iranian Journal of Basic Medical Sciences; Journal of Ayub Medical \\
& College, Abbottabad; Journal of Biological Sciences; Metabolic Syndrome and Related Disorders; Nutrition Journal; \\
& Nutrition Research; PLoS ONE; Psychiatry Research; Rheumatology International; The Journal of International Medical \\
& Research; Therapeutic Advances in Endocrinology and Metabolism; Transplantation Proceedings; Tropical Doctor; \\
& Vascular Health and Risk Management; World Journal of Medical Sciences
\end{tabular}




\section{PRISMA 2009 Flow Diagram}
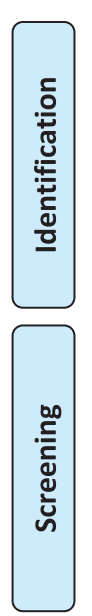

Records after duplicates removed $(n=451)$
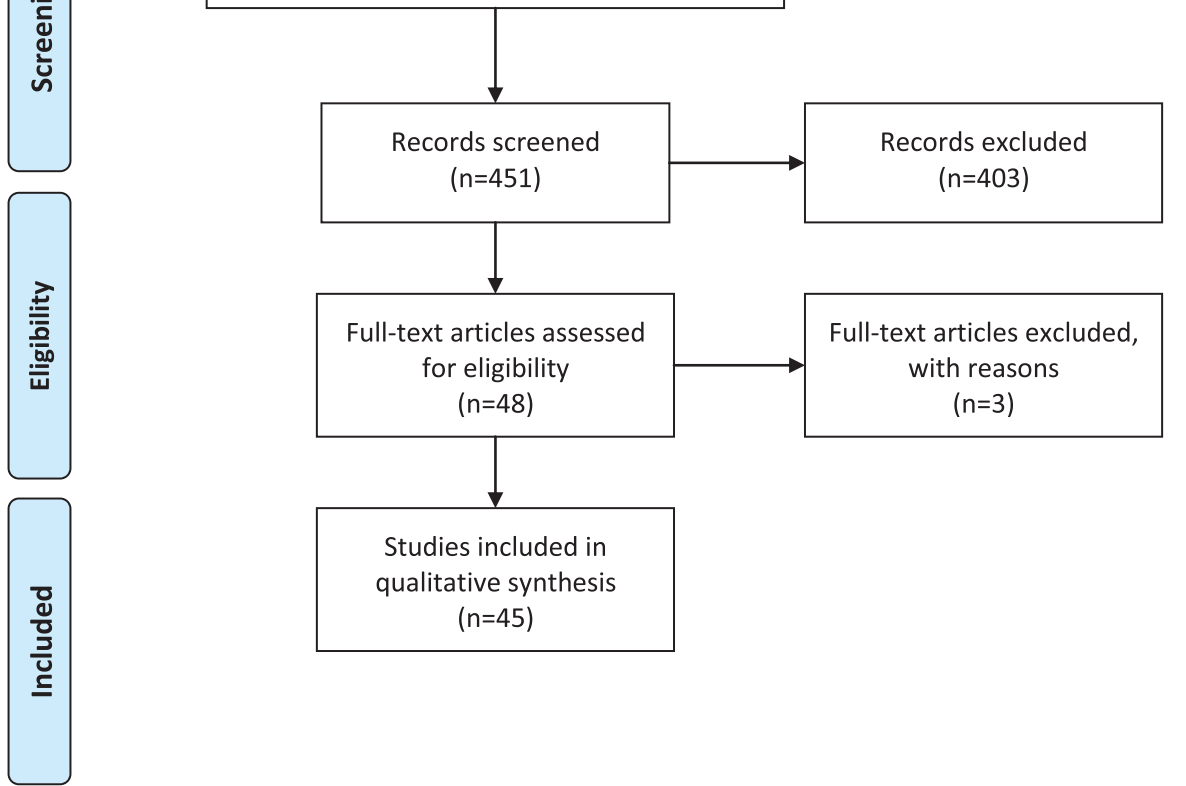

FIGURE 1 | Preferred Reporting Items for Systematic Reviews and Meta-Analyses 2009 Flow Diagram.

\section{RESULTS}

The initial search in databases yielded a pool of 925 items. After removing duplicates and not pertinent studies, as well as excluding studies with reasons (Table 2), 45 studies were included in the current systematic review (Table 3). Twentyfive studies focused on the impact of fasting on immune system in healthy subjects, while five investigated the impact of Ramadan on immune system in people suffering from autoimmune diseases (such as systemic lupus erythematosus or SLE, multiple sclerosis or MS, and inflammatory bowel disease or IBD). Three articles explored the effect of fast on immune system in patients with cardiac diseases, whereas one and eight investigations assessed the influence of fasting in pregnant women and athletes, respectively. One study was conducted among people with human immunodeficiency virus (HIV)/ acquired immunodeficiency syndrome, while another one was devoted to describe the impact of Ramadan in patients with
TABLE 2 | Studies excluded with reason.

\begin{tabular}{ll}
\hline Excluded study with reason & Reason for exclusion \\
\hline Razeghi Jahromi et al. (4) & Animal model \\
Shawky et al. (5) & Animal model \\
Sadek and Saleh (6) & Animal model
\end{tabular}

psychiatric disorders (schizophrenia). The remaining study recruited asthmatic people.

Sample-sizes ranged from 8 to 100 recruited subjects. Eighteen studies were carried out in Iran, six in Tunisia, four in Turkey, three in Indonesia, in Saudi Arabia, and in Egypt, two in Jordan, and one in France, in India, in Iraq, in Nigeria, in Qatar, and in United Arab Emirates. Age ranged from 15 to 70 years. Fasting went from 8 to $17 \mathrm{~h}$, depending on the country and on the year of investigation. Completion rate (subjects who completed the study out of the total sample) ranged from 100.0 
TABLE 3 | Studies on Ramadan Fasting and the Immunity System stratified by different topics.

\begin{tabular}{|c|c|c|c|c|c|c|c|c|c|}
\hline Topic & $\begin{array}{l}\text { Immunologic/inflammatory } \\
\text { markers studied }\end{array}$ & Reference & Country & $\begin{array}{l}\text { Study } \\
\text { design }\end{array}$ & Sample timing & $N$ & $\begin{array}{l}\text { Mean age/age } \\
\text { range (years) }\end{array}$ & Gender & Conclusion \\
\hline \multirow[t]{14}{*}{$\begin{array}{l}\text { Immune system } \\
\text { and healthy } \\
\text { subjects }\end{array}$} & $\begin{array}{l}\text { hs-CRP, GGT, DUSP1, and } \\
\text { interleukin } 1 \alpha(\text { (IL-1 } \alpha) \text { gene } \\
\text { expression in circulating } \\
\text { leukocytes }\end{array}$ & (7) & $\begin{array}{l}\text { Saudi } \\
\text { Arabia }\end{array}$ & PCS & $\mathrm{BR}, 10-15 \mathrm{~d} \mathrm{DR}$ & 23 & $\begin{array}{c}23.2 \pm 1.2 \\
(18-42)\end{array}$ & $M(18)+F(5)$ & $\begin{array}{l}\text { Mean level of GGT decreased during the fast. Mean morning } \\
\text { and evening DUSP1 level significantly increased during the fast, } \\
\text { even though diurnal rhythm was preserved. Morning IL-1 } \alpha \text { level } \\
\text { was higher than in the evening; however, mean value decreased } \\
\text { during the fast with respect to the period before the fast. Diurnal } \\
\text { rhythm of hs-CRP was lost }\end{array}$ \\
\hline & IL-6, hs-CRP & (8) & Iran & PCS & $\begin{array}{l}1 \text { w BR, } 4 \text { wDR, } \\
4 \text { w AR }\end{array}$ & 30 & $\begin{array}{c}29.44 \pm 7.4 \\
(20-35)\end{array}$ & M & No significant changes could be detected \\
\hline & $\begin{array}{l}\text { WBC count and tuberculin } \\
\text { induration }\end{array}$ & (9) & Iran & PCS & $4 \mathrm{w} \mathrm{DR}, 3 \mathrm{~m} \mathrm{AR}$ & 28 & $\begin{array}{l}19.21 \pm 3.83 \\
\quad(14-35)\end{array}$ & M & $\begin{array}{l}\text { Neutrophil count and lymphocyte count were significantly } \\
\text { reduced, no association between PPD test and Ramadan } \\
\text { fasting was noted }\end{array}$ \\
\hline & $\begin{array}{l}\text { Lipid peroxidation profile, } \\
\text { MDA }\end{array}$ & (10) & $\begin{array}{l}\text { Saudi } \\
\text { Arabia }\end{array}$ & PCS & $\mathrm{BR}, \mathrm{DR}, \mathrm{AR}$ & 8 & $\begin{array}{c}26.6 \pm 4.9 \\
(20-35)\end{array}$ & M & No significant changes could be detected \\
\hline & $\lg G, \lg A, \lg M$ levels & (11) & $\begin{array}{l}\text { Saudi } \\
\text { Arabia }\end{array}$ & PCS & $\mathrm{BR}, 2 \mathrm{wDR}$ & 23 & $\begin{array}{c}23.2 \pm 1.2 \\
(18-42)\end{array}$ & $M(18)+F(5)$ & Marked decrease in lgG level \\
\hline & $\begin{array}{l}\text { Pro-oxidant and antioxidant } \\
\text { profiles }\end{array}$ & (12) & Iran & PCS & $\begin{array}{l}1 w B R, 27 d \\
D R\end{array}$ & 23 & $25-65$ & $M(16)+F(7)$ & No significant changes \\
\hline & CRP, granulysin levels & (13) & Iran & PCS & $\begin{array}{l}29 \mathrm{dDR}, 4 \mathrm{~m} \\
\mathrm{AR}\end{array}$ & 44 & $41.15 \pm 13.6$ & M & $\begin{array}{l}\text { Statistically significant decrease in CRP, no differences in } \\
\text { granulysin level }\end{array}$ \\
\hline & TNF- $\alpha$ & (14) & Iran & PCS & $\begin{array}{l}1-2 \mathrm{~d} \text { DR, last } \\
3 \mathrm{~d} \text { of fasting }\end{array}$ & 70 & $47.88(30-70)$ & M & No changes in TNF- $\alpha$ \\
\hline & $\begin{array}{l}\text { C3, iNOS and SOD levels in serum } \\
\text { and the killing ability of PBMC } \\
\text { against Mycobacterium tuberculosis }\end{array}$ & (15) & Indonesia & PCS & $\begin{array}{l}7 \mathrm{dBR}, 7 \mathrm{dDR} \\
21 \mathrm{dDR}\end{array}$ & 30 & $\begin{array}{c}20.26 \pm 1.13 \\
(18-22)\end{array}$ & M & $\begin{array}{l}\text { Ramadan fasting was shown to enhance the killing ability of } \\
\text { macrophages against } M \text {. tuberculosis. Ramadan fasting did } \\
\text { not alter the serum levels of complement C3, iNOS, or SOD }\end{array}$ \\
\hline & $\begin{array}{l}\text { CXCL1, CXCL10, and CXCL12 } \\
\text { chemokines levels }\end{array}$ & (16) & Iran & PCS & $\mathrm{BR}, \mathrm{AR}$ & 58 & $20-40$ & M & $\begin{array}{l}\text { Significant decrease in BWC, pro-inflammatory chemokines } \\
\text { (CXCL1, CXCL10), and the constitutive chemokine (CXCL12), } \\
\text { TNF- } \alpha, \mathrm{LL}-2, \mathrm{IL}-8 \text {-fasting plays a role in controlling inflammation } \\
\text { via chemokines }\end{array}$ \\
\hline & $\begin{array}{l}\text { Serum IgG and lgM levels, } \\
\text { salivary lgA levels }\end{array}$ & (17) & Turkey & PCS & $\mathrm{BR}, 25 \mathrm{~d} \mathrm{DR}$ & 35 & $\begin{array}{l}35.86 \pm 11.07 \\
(20-59)\end{array}$ & M & $\begin{array}{l}\text { Ramadan fasting was not shown to result in severe } \\
\text { immunological disturbances. However, even though remaining } \\
\text { in the normal range, IgG and IgA decreased significantly, IgM } \\
\text { did not change. Lymphocyte number increased. No correlation } \\
\text { between immunoglobulin levels and } \\
\text { lymphocyte number could be found }\end{array}$ \\
\hline & $\begin{array}{l}\text { Serum, PBMC and macrophages } \\
\text { endorphin and endocannabinoid } \\
\text { levels }\end{array}$ & (18) & Indonesia & PCS & $\begin{array}{l}1 \mathrm{wBR}, 1 \mathrm{wDR}, \\
\text { and } 3 w \mathrm{DR}\end{array}$ & 27 & $\begin{array}{l}20.26 \pm 1.13 \\
\quad(18-22)\end{array}$ & M & $\begin{array}{l}\text { Endorphin levels were significantly elevated in serum, PBMC, } \\
\text { and macrophages during Ramadan as compared to before. } \\
\text { Additionally, endocannabinoid levels were significantly elevated } \\
\text { in serum and PBMC. In contrast, endocannabinoid levels were } \\
\text { noted to be significantly low in macrophages. The impact of } \\
\text { Ramadan fasting on these molecules } \\
\text { appears to be subtle }\end{array}$ \\
\hline & IFN- $\gamma$, TNF- $\alpha$, iNOS, and SOD & (19) & Indonesia & PCS & $\begin{array}{l}1 \mathrm{wBR}, 1 \mathrm{wDR}, \\
\text { and } 3 w \mathrm{WR}\end{array}$ & 27 & $\begin{array}{c}20.26 \pm 1.13 \\
(18-22)\end{array}$ & M & $\begin{array}{l}\text { Significant increase of IFN- } \gamma \text {, TNF- } \alpha \text {, and iNOS, significant } \\
\text { decrease } \\
\text { of SOD- Ramadan fasting induces activation and inflammation } \\
\text { while } \\
\text { decreasing oxidative stress on macrophages }\end{array}$ \\
\hline & Urinary 15FIP levels & (20) & Jordan & PCS & $\begin{array}{l}1 \mathrm{w} B R, 22 \mathrm{~d} D R \\
30 \mathrm{~d} A R\end{array}$ & 50 & $18-51$ & $M(23)+F(27)$ & Levels of urinary 15FIP were significantly elevated \\
\hline
\end{tabular}




\begin{tabular}{|c|c|c|c|c|c|c|c|c|c|c|}
\hline Topic & \multicolumn{2}{|c|}{$\begin{array}{l}\text { Immunologic/inflammatory } \\
\text { markers studied }\end{array}$} & Reference & Country & $\begin{array}{l}\text { Study } \\
\text { design }\end{array}$ & Sample timing & $N$ & $\begin{array}{l}\text { Mean age/age } \\
\text { range (years) }\end{array}$ & Gender & Conclusion \\
\hline & \multicolumn{2}{|c|}{$\begin{array}{l}\text { Circulating pro-inflammatory } \\
\text { cytokines (L- } 1 \beta \text {, LL-6, and TNF- } \alpha \text { ), } \\
\text { immune cells (total leukocytes, } \\
\text { monocytes, granulocytes, and } \\
\text { lymphocytes) }\end{array}$} & (21) & Jordan & PCS & $\begin{array}{l}1 \mathrm{w} B R, 3 \text { w DR, } \\
1 \mathrm{~m} \mathrm{AR}\end{array}$ & 50 & $18-51$ & $M(21)+F(29)$ & $\begin{array}{l}\text { Statistically significant decrease during Ramadan with } \\
\text { respect to the period before and after. Ramadan } \\
\text { induces immune attenuation }\end{array}$ \\
\hline & \multicolumn{2}{|c|}{ IL-1 $\alpha$, IL-2, IL-6, and IL-8 } & (22) & Iraq & $\begin{array}{l}\text { Case-control } \\
\text { study }\end{array}$ & n.a. & $\begin{array}{l}30 \text { cases and } \\
30 \text { controls }\end{array}$ & $\begin{array}{l}34.5 \pm 11.5 \\
(21-58)\end{array}$ & n.a. & $\begin{array}{l}\text { Ramadan may induce immunomodulation but changes in } \\
\text { interleukins did not reach statistical significance }\end{array}$ \\
\hline & \multicolumn{2}{|c|}{ MDA and GSH levels } & (23) & Turkey & PCS & $\mathrm{BR}, 28 \mathrm{~d} \mathrm{DR} / \mathrm{AR}$ & 45 & $28.7(21-51)$ & $M(23)+F(22)$ & $\begin{array}{l}\text { MDA levels increased in both genders; however, the increase } \\
\text { was statistically significant only in female subjects. GSH levels } \\
\text { decreased in males, however, increased in females-fasting may } \\
\text { modify the immune response by inducing oxidative stress, having } \\
\text { a gender-specific effect }\end{array}$ \\
\hline & \multicolumn{2}{|c|}{$\begin{array}{l}\text { Neutrophil phagocytosis, serum } \\
\text { opsonization power, and NBT } \\
\text { reduction }\end{array}$} & (24) & Iran & PCS & $B R, A R$ & 13 & $28-54$ & M & $\begin{array}{l}\text { Ramadan fasting had a beneficial effect on neutrophils } \\
\text { phagocytic function }\end{array}$ \\
\hline & \multicolumn{2}{|c|}{$\begin{array}{l}\text { MDA, GSH, glutathione peroxidase, } \\
\text { and catalase levels }\end{array}$} & (25) & $\begin{array}{l}\text { United } \\
\text { Arab } \\
\text { Emirates }\end{array}$ & PCS & $\begin{array}{l}2 \mathrm{dBR}, 14 \mathrm{dDR}, \\
28 \mathrm{dDR}\end{array}$ & 14 & $25-58$ & $M(9)+F(5)$ & $\begin{array}{l}\text { Ramadan fasting was not associated with alterations in } \\
\text { parameters that reflect oxidative stress or biochemical markers }\end{array}$ \\
\hline & \multicolumn{2}{|c|}{ Neutrophil activity } & (26) & Iran & PCS & $\mathrm{BR}, \mathrm{AR}$ & 24 & $26.5(18-35)$ & M & No significant changes in neutrophil activity \\
\hline & \multicolumn{2}{|c|}{$\begin{array}{l}\text { Homocysteine, CRP, and } \\
\text { IL-6 levels }\end{array}$} & (27) & Turkey & $\begin{array}{l}\text { Case-control } \\
\text { study }\end{array}$ & $\begin{array}{l}1 \mathrm{wBR}, 4 \mathrm{wDR} \\
20 \mathrm{dAR}\end{array}$ & $\begin{array}{l}40 \text { cases and } \\
28 \text { controls }\end{array}$ & $20-40$ & $M(34)+F(34)$ & $\begin{array}{l}\text { Statistically significant decrease in IL-6, CRP, } \\
\text { homocysteine levels }\end{array}$ \\
\hline & \multicolumn{2}{|l|}{ CIC levels } & (28) & Iran & PCS & $B R, A R$ & 28 & 26.2 & M & No significant changes in ClC levels \\
\hline & \multicolumn{2}{|c|}{$\mathrm{CL}$ activity and $\mathrm{CIC}$ levels } & (29) & Iran & PCS & $B R, A R$ & 21 & $26.5(18-35)$ & M & No significant differences in CL activity and $\mathrm{CIC}$ levels \\
\hline & \multicolumn{2}{|c|}{$\mathrm{C} 3, \mathrm{C} 4, \mathrm{CHSO}$} & (30) & Iran & PCS & $\mathrm{BR}, \mathrm{AR}$ & 50 & $20-25$ & $M+F$ & No significant changes \\
\hline & \multicolumn{2}{|c|}{ MDA, conjugated dienes } & (31) & Iran & PCS & $\mathrm{BR}, \mathrm{AR}$ & 46 & $30-60$ & M & $\begin{array}{l}\text { Statistically significant decrease in MDA, increase in conjugated } \\
\text { dienes induced by the Ramadan fasting }\end{array}$ \\
\hline \multirow[t]{5}{*}{$\begin{array}{l}\text { Immune system } \\
\text { and autoimmune } \\
\text { diseases }\end{array}$} & SLE & $\begin{array}{l}\text { Levels of } \\
\text { autoantibodies }\end{array}$ & (32) & Iran & $\begin{array}{l}\text { Case-control } \\
\text { study }\end{array}$ & $\mathrm{BR} / \mathrm{DR}, \mathrm{AR}$ & $\begin{array}{l}21 \text { cases } \\
\text { and } 19 \\
\text { controls (out } \\
\text { of } 80 \text { eligible } \\
\text { patients, } 38 \\
\text { cases and } 42 \\
\text { controls) }\end{array}$ & $\begin{array}{l}39.7 \pm 13.4 \\
\text { for cases, } \\
40.2 \pm 11.2 \text { for } \\
\text { controls }\end{array}$ & $\mathrm{F}$ & $\begin{array}{l}\text { Anti-dsDNA and C3 levels significantly increased levels. No } \\
\text { changes in disease activity or quality of life were noted- } \\
\text { Ramadan fasting has minimal and non-detrimental effects of } \\
\text { on SLE patients }\end{array}$ \\
\hline & MS & $\begin{array}{l}\text { Antioxidant } \\
\text { status }\end{array}$ & (33) & Egypt & $\begin{array}{l}\text { Case-control } \\
\text { study }\end{array}$ & $\begin{array}{l}\text { BR, DR, AR } \\
\text { (1 year of } \\
\text { follow-up) }\end{array}$ & $\begin{array}{l}15 \text { cases, } 15 \\
\text { controls }\end{array}$ & $15-45$ & n.a. & $\begin{array}{l}\text { No significant differences in relapse rate, EDSS score, or } \\
\text { contrast enhanced lesions on MRI-Ramadan fasting did not } \\
\text { pose any unfavorable outcomes in MS patients. On the contrary, } \\
\text { Ramadan could improve antioxidative status and protect against } \\
\text { relapse, by reducing levels of uric acid }\end{array}$ \\
\hline & $\begin{array}{l}\text { Rheumatoid } \\
\text { arthritis (RA) }\end{array}$ & CIC & (34) & India & PCS & $\mathrm{BR}, \mathrm{AR}$ & 30 & $45-60$ & $M(5)+F(25)$ & Ramadan could be beneficial for RA patients \\
\hline & MS & $\begin{array}{l}\text { Frequency of } \\
\text { relapse rate } \\
\text { and EDSS } \\
\text { score }\end{array}$ & (35) & Iran & $\begin{array}{l}\text { Case-control } \\
\text { study }\end{array}$ & DR & $\begin{array}{l}80 \text { (40 cases, } \\
40 \text { controls) }\end{array}$ & $\begin{array}{l}28.73 \pm 6.80 \\
\text { for cases } \\
31.10 \pm 9.09 \text { for } \\
\text { controls }\end{array}$ & $M(29)+F(51)$ & $\begin{array}{l}\text { No significant differences in relapse rate or EDSS score- } \\
\text { Ramadan fasting did not pose any unfavorable outcomes } \\
\text { in MS patients }\end{array}$ \\
\hline & $\mathrm{IBD}$ & $\begin{array}{l}\text { Disease } \\
\text { severity and } \\
\text { quality of life }\end{array}$ & (36) & Iran & PCS & $\mathrm{BR}, \mathrm{AR}$ & 60 & $35.5 \pm 15$ & $M(27)+F(33)$ & $\begin{array}{l}\text { No correlation between fasting, disease severity, or } \\
\text { quality of life was documented. This result highlights the } \\
\text { safety of Ramadan fasting } \\
\text { in IBD patients }\end{array}$ \\
\hline
\end{tabular}


TABLE 3 | Continued

\begin{tabular}{|c|c|c|c|c|c|c|c|c|c|c|}
\hline Topic & \multicolumn{2}{|c|}{$\begin{array}{l}\text { Immunologic/inflammatory } \\
\text { markers studied }\end{array}$} & Reference & Country & $\begin{array}{l}\text { Study } \\
\text { design }\end{array}$ & Sample timing & $N$ & $\begin{array}{l}\text { Mean age/age } \\
\text { range (years) }\end{array}$ & Gender & Conclusion \\
\hline $\begin{array}{l}\text { Immune system } \\
\text { and asthmatic } \\
\text { patients }\end{array}$ & \multicolumn{2}{|l|}{ WBC, hs-CRP } & (37) & Iran & $\begin{array}{l}\text { Case-control } \\
\text { study }\end{array}$ & $3-5 d B R, A R$ & $\begin{array}{l}29 \text { ( } 15 \text { cases } \\
\text { and } 14 \\
\text { controls) }\end{array}$ & $\begin{array}{l}49.28 \pm 12.54 \\
\text { (cases), } \\
37.5 \pm 7.86 \\
\text { (controls) }\end{array}$ & n.a. & Decrease in hs-CRP \\
\hline \multirow{3}{*}{$\begin{array}{l}\text { Immune system } \\
\text { and cardiac } \\
\text { diseases }\end{array}$} & \multicolumn{2}{|c|}{ PP, MDA, and GSH levels } & (38) & Egypt & $\mathrm{n} / \mathrm{a}$ & $\begin{array}{l}\text { From } 1 \text { w BR to } \\
6 \text { w AR }\end{array}$ & n/a & $55 \pm 5$ & n.a. & $\begin{array}{l}\text { Significant reduction of PP and MDA and significant increase in } \\
\text { GSH }\end{array}$ \\
\hline & \multicolumn{2}{|l|}{ hs-CRP levels } & (39) & Qatar & PCS & $\mathrm{BR} / \mathrm{DR}, \mathrm{AR}$ & 56 & $\begin{array}{l}18 \leq 50 y \\
38>50 y\end{array}$ & $M(45)+F(11)$ & $\begin{array}{l}\text { No cardiac or non-cardiac morbidity or mortality was reported. } \\
\text { Biochemical levels of hs-CRP were not shown to significantly } \\
\text { vary-Ramadan fasting is safe in cardiac patients with stable } \\
\text { cardiac conditions }\end{array}$ \\
\hline & \multicolumn{2}{|c|}{$\begin{array}{l}\text { hs-CRP and homocysteine } \\
\text { levels, complete blood count }\end{array}$} & (40) & Iran & PCS & $\begin{array}{l}7 \mathrm{~d} B R, 1 \mathrm{~d} D R \\
2 \mathrm{~d} D R, \text { from } \\
27 \mathrm{~d} \text { DR to } 6 \text { AR }\end{array}$ & 82 & $\begin{array}{c}54.0 \pm 10.0 \\
(29-70)\end{array}$ & $M(38)+F(44)$ & $\begin{array}{l}\text { Significant improvement of the 10-year coronary heart disease } \\
\text { risk. No significant alterations were found in hs-CRP and } \\
\text { homocysteine levels - Ramadan fasting improves CVD risk factors }\end{array}$ \\
\hline $\begin{array}{l}\text { Immune system } \\
\text { and human } \\
\text { immunodeficiency } \\
\text { virus patients }\end{array}$ & \multicolumn{2}{|c|}{$\begin{array}{l}\text { Cluster differentiation } 4 \text { (CD4) } \\
\text { cell count, viral load }\end{array}$} & (41) & Nigeria & PCS & $\mathrm{BR}, \mathrm{DR}, \mathrm{AR}$ & 17 & n.a. & n.a. & $\begin{array}{l}\text { No changes in CD4 cell count, viral load, and hematocrit could } \\
\text { be detected }\end{array}$ \\
\hline $\begin{array}{l}\text { Immune system } \\
\text { and pregnant } \\
\text { women }\end{array}$ & \multicolumn{2}{|c|}{ Serum TAS, TOS, and OSI } & (42) & Turkey & $\begin{array}{l}\text { Case-control } \\
\text { study }\end{array}$ & n.a. & $\begin{array}{l}42 \text { cases and } \\
\text { ( } 48 \text { potentially } \\
\text { eligible) } 30 \\
\text { controls }\end{array}$ & $\begin{array}{l}30.10(20-43) \\
\text { for cases, } 29.50 \\
(18-46) \text { for } \\
\text { controls }\end{array}$ & $\mathrm{F}$ & $\begin{array}{l}\text { Ramadan fasting did not have a significant effect on the maternal } \\
\text { oxidative stress, fetal development, maternal complications, or } \\
\text { fetal birth weight }\end{array}$ \\
\hline $\begin{array}{l}\text { Immune system } \\
\text { and psychiatric } \\
\text { patients }\end{array}$ & \multicolumn{2}{|c|}{$\begin{array}{l}\text { WBC, granulocytes, } \\
\text { lymphocytes, monocytes, } \\
\text { fibrinogen, and hs-CRP }\end{array}$} & (43) & Egypt & PCS & $\mathrm{BR}, 4 \mathrm{w} \mathrm{DR}$ & $\begin{array}{l}100 \text { out of } \\
134 \text { eligible } \\
\text { patients }\end{array}$ & $\begin{array}{c}39.6 \pm 13.4 \text { with } \\
\text { metabolic } \\
\text { syndrome } \\
37.9 \pm 13.7 \\
\text { without } \\
\text { metabolic } \\
\text { syndrome }\end{array}$ & M & $\begin{array}{l}\text { Increase in inflammatory markers in patients with schizophrenia } \\
\text { and metabolic disorders }\end{array}$ \\
\hline \multirow[t]{5}{*}{$\begin{array}{l}\text { Immune systems } \\
\text { and athletes }\end{array}$} & Soccer players & TAS & (44) & Tunisia & PCS & $\begin{array}{l}1 \text { w BR, } 2 \text { w DR, } \\
4 \text { w DR }\end{array}$ & 12 & $17.52 \pm 0.2$ & M & Increased TAS \\
\hline & Rugby players & $\begin{array}{l}\operatorname{lgG}, \operatorname{lgM}, \lg A \\
\text { and IgE, C3, } \\
\text { C4, and blood } \\
\text { count cells }\end{array}$ & (45) & Iran & PCS & $\mathrm{BR}, \mathrm{AR}$ & 90 & $16-36$ & n.a. & $\begin{array}{l}\text { Increase in IgA and C4, decrease in percentage of lymphocytes } \\
\text { and neutrophils. Ramadan could protect against exercise- } \\
\text { induced/ } \\
\text { related infections }\end{array}$ \\
\hline & Soccer players & $\begin{array}{l}\text { Homocysteine } \\
\text { and hs-CRP } \\
\text { levels }\end{array}$ & (46) & Tunisia & PCS & $\begin{array}{l}1 \mathrm{wBR}, 2 \mathrm{wDR}, \\
4 \mathrm{wDR}\end{array}$ & 15 & $17.3 \pm 0.3$ & M & $\begin{array}{l}\text { Higher levels of HDL-C and APO-Al were documented and a } \\
\text { decrease of low density lipoprotein, apolipoprotein B, lipoprotein } \\
\text { particles, homocysteine, and hs-CRP-fasting and exercise work } \\
\text { synergistically to reduce body mass, improve lipid profile and } \\
\text { modulate the inflammatory status in athletes }\end{array}$ \\
\hline & $\begin{array}{l}\text { Recreational } \\
\text { bodybuilders }\end{array}$ & CRP & (47) & Tunisia & $\begin{array}{l}\text { Case-control } \\
\text { study }\end{array}$ & $2 d \mathrm{BR}, 29 \mathrm{~d} \mathrm{DR}$ & $\begin{array}{l}16 \text { ( } 9 \text { cases } \\
\text { and } 7 \\
\text { controls) }\end{array}$ & $\begin{array}{c}24 \pm 3 \text { for cases } \\
26 \pm 3 \text { for } \\
\text { controls }\end{array}$ & M & No changes \\
\hline & $\begin{array}{l}\text { Physical education } \\
\text { students }\end{array}$ & IL-12 levels & (48) & Tunisia & PCS & $\begin{array}{l}\text { 1 w DR, } 4 \text { w DR, } \\
1-3 \text { wAR }\end{array}$ & 9 & $22.1 \pm 0.2$ & M & $\begin{array}{l}\text { IL-12 was significantly decreased during Ramadan in comparison } \\
\text { to after Ramadan. The fluctuation of IL-12 levels has been } \\
\text { attributed to changes in dietary intake as well as sleep pattern } \\
\text { alterations }\end{array}$ \\
\hline
\end{tabular}




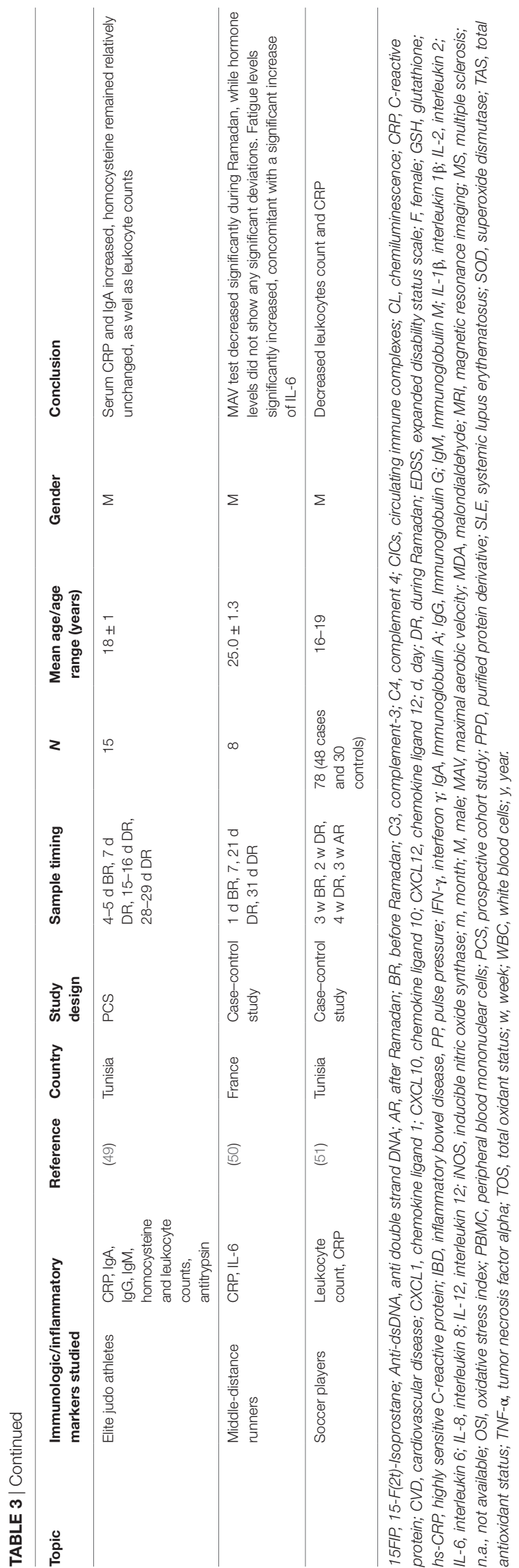

to $17.5 \%$. Concerning gender, 23 researches investigated samples made up of only males, whereas 20 studies recruited mixed samples. Only two studies were conducted with female samples. Regarding recruiting and sampling strategies, most studies relied on convenience samples/purposive sampling, whereas only two studies $(7,11)$ computed a priori sample-size power. Ten studies were case-control studies, while the remaining ones were observational prospective cohort studies.

\section{IMMUNITY CHANGES IN HEALTHY INDIVIDUALS}

Latifynia et al. (28) investigated the influence of Ramadan fasting on neutrophils respiratory burst and circulating immune complexes (CICs) in 24 healthy male volunteers aged 18-45 years. On chemiluminescence (CL), no statistically significant changes on neutrophil activity were obtained, eliminating hazardous effect of Ramadan fasting on the innate system.

In a closely similar study, levels of CICs were determined using several techniques including polyethylene glycol precipitation method, quantitative CL and circulating immune techniques. Authors investigated a sample of 28 healthy students residing in dormitory of Tehran University. The mean age of the enrolled subjects was 26.2 years. The results of this study showed a mean CIC level of $2.04 \pm 1.86$ before Ramadan and $2.63 \pm 2.1$ after Ramadan ( $p$-value $=0.05)$. Such finding highlighted the absence of significant changes of CIC levels before and after Ramadan fasting. Of note, CIC levels increased in 17 subjects, whereas in 11 subjects the levels of CIC decreased. Of the enrolled subjects, only six had levels that did not lie within the normal range. In addition, three cases had low CIC levels before Ramadan and remained abnormal thereafter (28). Similar results were replicated in additional studies: CIC levels as well as complement-3 (C3), C4 levels were not demonstrated to be significantly altered as a result of Ramadan fasting $(29,30)$.

In an additional research, the neutrophil respiratory burst was probed in a small sample of 21 healthy male students from Tehran aged $18-25$ years. In $52 \%$ of the cases, CL activity and CIC levels pre and post Ramadan remained within the normal range and some patients had an insignificant decrease or increase of CL and CIC levels. In $24 \%$ of the cases, CL and CIC levels were measured to be high before Ramadan, with normalization of both parameters after the month of Ramadan. In an additional $24 \%$ of the patients, an elevation of both CL and CIC levels was witnessed after Ramadan fasting. Based on the lack of significant differences in CL and CIC levels before and after Ramadan, Ramadan fasting was not shown to influence neutrophil respiratory burst (26).

The intermittent fasting approach has been hypothesized to positively affect the inflammatory state and has been shown to reduce inflammation and prevent cancer promotion in animal models. In humans, a cross sectional study of 50 healthy volunteers (21 men and 29 women) was conducted to explore the fluctuations of circulating pro-inflammatory cytokines (interleukin $1 \beta$ or IL-1 $\beta$, interleukin 6 or IL- 6 , tumor necrosis factor alpha or TNF- $\alpha$ ), immune cells (total leukocytes, monocytes, granulocytes, 
and lymphocytes) at three instances: 1 week before Ramadan, 3 weeks after Ramadan, and 1 month after the conclusion of Ramadan. The pro-inflammatory cytokines IL- $1 \beta$, IL- 6 , and TNF- $\alpha$ showed a significant decrease during Ramadan ( $p$-value $<0.05)$. In addition, immune cells significantly dropped during Ramadan, albeit remaining within the reference ranges (21). In another case-control study including 30 fasting patients and 30 nonfasters, interleukin $1 \alpha$, interleukin 2 , IL- 6 , and interleukin 8 were shown to be decreased although not reaching a significant level, which seems to suggest a possible immunomodulatory influence of Ramadan fasting (22). In a prospective cohort study, TNF- $\alpha$ levels were not shown to be changed post fasting (14). Taken together, these results support the perception of immune attenuation during Ramadan.

The role of Ramadan fasting on the levels of immunoglobulins was explored by Develioglu et al. (17) who collected blood and saliva samples of 35 healthy male volunteers (mean age of 38 years). The samples were collected 1 week before and during the first week of Ramadan. Immunoglobulin G (IgG) and immunoglobulin A (IgA) concentrations decreased significantly during Ramadan, however, still remained within the normal range. In comparison, the levels of immunoglobulin $\mathrm{M}$ remained stable, with no significant increase or decrease. In an additional study, only levels of IgG were shown to be markedly decreased (11). Taken together, the results highlighted that Ramadan fasting was not shown to result in drastic disturbances.

Akrami Mohajeri et al. (16) studied chemokine (C-X-C motif) ligand 1 (CXCL1), chemokine (C-X-C motif) ligand 10 (CXCL10) and chemokine (C-X-C motif) ligand 12 (CXCL12) chemokines levels using enzyme-linked immunosorbent assay (ELISA), in a sample of 58 healthy fasting subjects, aged 20-40 years. Their results showed a significant decrease of the pro-inflammatory chemokines (CXCL1, CXCL10) and the constitutive chemokine (CXCL12). These chemokines are known to be downstream targets of TNF- $\alpha$, which has been shown to be downregulated during fasting (21), even though some other studies found that TNF- $\alpha$ was increased (19) or remained unchanged (14). Thus, fasting has been shown to play a role in controlling inflammation via chemokines.

In another report, 40 healthy fasting volunteers of normal weight (20 females aged 20-38 years and 20 males aged 23-39 years) were recruited and compared to 28 healthy, ageand body mass index (BMI)-matched non-fasting volunteers (14 males, 14 females). Biochemical parameters were monitored including C-reactive protein (CRP), IL-6, and homocysteine or hcy levels. The levels of the inflammatory markers (IL-6, CRP, and hcy) were shown to be significantly decreased as a result of Ramadan fasting in both genders as compared to their primary basal values (50). Gorjipour et al. (13) and Ajabnoor et al. (7) showed similar significant decrease of CRP, whereas only one study failed to demonstrate this effect (8).

The influence of Ramadan fasting on complement C3, inducible nitric oxide synthase (iNOS), superoxide dismutase (SOD) levels in serum and peripheral blood mononuclear cells (PBMC) and macrophages in 30 healthy male volunteers was also monitored to determine whether fasting could alter the ability of PBMC to kill Mycobacterium tuberculosis (M. tuberculosis).
Ramadan fasting was shown to enhance the killing ability of PBMC and macrophages against M. tuberculosis when compared to serum activity. There was no alteration on the serum levels of complement C3, iNOS, or SOD during Ramadan fasting (15). Furthermore, Ramadan fasting in a sample of 30 male patients was shown to enhance macrophagic killing abilities against tuberculosis (15).

The influence of Ramadan fasting on tuberculin skin test or purified protein derivative $\mathrm{PPD}$, which is a delayed type hypersensitivity immune response test, has also been addressed for the possible role of Ramadan in immunomodulation. Twenty-eight healthy males were monitored for their white blood cell count and tuberculin induration on the fourth week of Ramadan and 3 months after Ramadan. It was found that while neutrophil and lymphocyte counts were significantly reduced, no association between PPD test and Ramadan fasting was noted (9). In healthy individuals, neutrophil phagocytic function was shown to be improved (24).

From an immunologic point of view, Ramadan fasting could be perceived as a stressor leading to alteration of immune system. Macrophage is usually stimulated to secrete myriad of molecules and chemokines in response to stress and oxidative damage. Lahdimawan et al. (19) investigated the functions of macrophage activity in a sample of 27 male healthy volunteers aged 18-22 years who fasted Ramadan. Significant increases of interferon-gamma, TNF-alpha, and iNOS were noted, while SOD decreased significantly. The results of this study suggest that Ramadan fasting induces activation and inflammation while decreasing oxidative stress on macrophages.

The role of Ramadan fasting as immunologic stressor intrigued researchers to study its impact on endorphin and endocannabinoid levels. Twenty-seven healthy male volunteers aged 18-22 years were enrolled in the study. Blood samples were analyzed using ELISA method for endorphin and endocannbinoid in serum, PBMC, and macrophages. Endorphin levels were noted to be significantly elevated in serum, PBMC and macrophages during Ramadan as compared to before. Additionally, endocannabinoid levels were significantly elevated in serum and PBMC. In contrast, endocannabinoid levels were noted to be significantly low in macrophages. The impact of Ramadan fasting on these molecules appears to be subtle. Endorphins and endocannabinoids share an integral role of immune system regulation by inhibition of $\mathrm{T}$ helper cell function and downregulation of antibody production (18).

The influence of Ramadan fasting on the markers of oxidative stress and the biochemical markers of cellular damage in healthy subjects was explored in 14 healthy volunteers, nine men and five women, aged 25-58 years. In these subjects, malondialdehyde (MDA), glutathione (GSH), GSH peroxidase, and catalase levels were monitored. The researchers concluded that, besides the mild reduction of lipid peroxidase levels, Ramadan fasting was not associated with alterations in parameters that reflect oxidative stress or biochemical markers (25). These results were replicated in additional studies that showed a lack of significant change in oxidative stress after Ramadan fasting $(10,12,31)$.

Isoprostans, which are prostaglandin F2 like compounds, possess high sensitivity and specificity to oxidative stress. The 
measurement of prostaglandin F2 has been shown to provide insight to the oxidative stress in the patient's body. The impact of Ramadan fasting on the oxidative stress was measured in a sample of 50 healthy subjects ( 23 men and 27 women) by probing the levels of the 15-F(t2)-Isoprostane (15FIP). The levels of urinary 15FIP was significantly elevated when measured in the third week of Ramadan, a finding that was concomitant with significant increase of the body weight and total body fat present. The increase of 15FIP is viewed as reflection of compensatory mechanism known as metabolic adaptation theory, which serves the purpose of opposing further weight change. Increased fat percentage and weight gain (which usually occur in Ramadan) are associated with increased fat oxidation, which leads to increased levels of 15FIP (20).

While the majority of the studies showed a rather neutral effect of Ramadan fasting on the immune system, Sülü et al. (23) investigated MDA and GSH levels in a sample of 45 healthy volunteers (22 females, 23 males, aged 21-51 years, mean age 28.7 years). MDA levels increased in both genders; however, the increase was statistically significant only in female subjects. GSH levels decreased in males, however, increased in females. The authors concluded that the impact of Ramadan fasting on the immune system may be different depending on the socioeconomic status, nutritional habits, and metabolic structure of the people. The same explanation was applied by the authors regarding the induction of oxidative stress that may develop during fasting.

In conclusion, Ramadan's influence on the immune system still requires further elucidation, yet general trends can be identified. Ramadan fasting has a modulatory effect on chemokine network, oxidative stress and adaptive, and innate immunity.

\section{IMMUNITY CHANGES IN AUTOIMMUNE DISEASES}

Most of the studies addressing the influence of Ramadan fasting on the immune system have been studied on healthy subjects. Research addressing the impact of Ramadan fasting on the etiopathogenesis as well as the progression and of autoimmune disease is limited. Goharifar et al. (32) conducted a case-control study investigating the impact of Ramadan fasting on SLE disease activity. Forty SLE quiescent patients were enrolled (21 fasting cases, and 19 non-fasting controls). SLE disease activity index, quality of life, and levels of autoantibodies were monitored 1 day before Ramadan, 1 day after Ramadan, and 3 months after Ramadan. Anti-dsDNA is one of the most specific autoantibodies in SLE. This antibody is associated with more severe SLE and with glomerulonephritis. Its level was found to be significantly increased in the fasting group after Ramadan fasting as compared to non-fasters. The levels of Anti-dsDNA remained significantly high after 3 months. Similarly, C3 levels were significantly elevated in the cases versus control group. In contrast, C3 levels dropped to baselines at 3 months. These changes were not accompanied by changes in disease activity or quality of life. These findings highlight the minimal and non-detrimental effects of Ramadan fasting in SLE patients.
The influence of Ramadan fasting on MS disease progression was investigated in two independent studies. The first study, which monitored 30 MS patients with an expanded disability status scale (EDSS) score $<3$, failed to reveal any significant differences in relapse rate, EDSS score or contrast enhanced lesions on magnetic resonance imaging of the patients who fasted versus the non-fasters (33). Likewise, an additional study on 80 MS patients with EDSS score of $<3$ did not show any significant increase in the frequency of relapse rate or EDSS score changes at 6 months follow-up (35). Therefore, Ramadan fasting did not pose any unfavorable outcomes in MS patients.

Tavakkoli et al. (36) conducted a cohort study to investigate the impact of Ramadan fasting on IBD progression. In 60 investigated patients, no correlation between fasting, disease severity, or quality of life was documented. This results highlight the safety of Ramadan fasting in IBD patients.

The influence of Ramadan fasting on other autoimmune disease has not been investigated so far. In rheumatoid arthritis (RA), Sharma et al. (34) showed a decrease in CIC levels in $70 \%$ of patients after fasting in comparison to pre-Ramadan levels, which suggests a possible beneficial role of fasting in RA patients. In murine models, fasting mimicking diets such as calorie restriction have been studied for their possible impact on autoimmune disease course (52). In Type 1 diabetes mellitus, caloric restriction was shown to improve glycemic control, downregulate inflammatory cytokines, such as interleukin 4, and IL-6, and upregulate anti-inflammatory cytokines as interleukin 10 (53). In MS, fasting mimicking diets were shown to attenuate symptoms by modulating immune cells and promoting oligodendrocyte regeneration (54).

\section{IMMUNITY CHANGES IN FASTING PATIENTS WITH CARDIAC DISEASES}

The effects of Ramadan fasting on the cardiac status of cardiac patients have not been clarified thus far. Khafaji et al. (39) investigated the possible relationship by examining the clinical progression, as well as leptin levels, and high sensitive (hs)CRP levels before, during and after Ramadan in a sample of 56 patients $(80.4 \%$ were male, $67.9 \%$ were aged $>50$ years $)$ of different stable cardiac illnesses. $71.4 \%$ did not complain for any fluctuation of their symptoms, whereas $28.6 \%$ had improvement of their symptoms. Of note, higher compliance to medication occurred during Ramadan as compared to after. Moreover, $90 \%$ of the patients were compliant with diet during Ramadan with no significant changes in body weight. No cardiac or noncardiac morbidity or mortality was reported. Biochemical levels of cholesterol, leptin and hs-CRP were not shown to significantly vary. Therefore, these results substantiate the safety of Ramadan fasting in cardiac patients with stable cardiac conditions. The effect of Ramadan fasting on cardiovascular risk factors was further investigated in a prospective observational study in a group of 82 patients ( 38 males and 44 females, aged 29-70 years, mean $54.0 \pm 10$ years) with at least one cardiovascular risk factor including coronary artery disease, metabolic syndrome, or cerebrovascular disease (CVD). Enrolled individuals were evaluated at least $10 \mathrm{~h}$ after fasting, before, and after Ramadan. 
Fasting samples were obtained including lipid profile, fasting blood sugar and insulin, hcy, hs-CRP and complete blood count; as well as blood pressure was measured and BMI was calculated. Fasting Ramadan led to a significant improvement of the 10-year coronary heart disease risk based on the Framingham risk score from the data collected above. No significant alterations were found in hs-CRP and hcy levels. These results point toward the usefulness of Ramadan fasting in improving CVD risk factors (40). Furthermore, in hypertensive patients, fasting has been shown to significantly reduce pulse pressure in the fasting hypertensive patients versus healthy controls. Additionally, MDA was shown to be significantly decreased, in contrast, GSH was significantly increased (38).

\section{IMMUNITY CHANGES IN FASTING PREGNANT WOMEN}

Ozturk et al. (42) investigated the influence of Ramadan fasting during pregnancy on the maternal and the fetus status in a prospective controlled study. They enrolled 42 fasting and 30 non-fasting women in their second trimester of pregnancy. Total antioxidant status (TAS), total oxidant status (TOS), and the oxidative stress index (OSI) were determined from serum samples. Additionally, maternal complications, birth weight as well as other parameters were documented at the end of pregnancy.

The only significant finding was an elevated TAS in the fasting group; however, non-significant differences were documented in TOS and OSI. Their results showed that Ramadan fasting did not have a significant effect on the maternal oxidative stress, fetal development, maternal complications or fetal birth weight.

\section{RAMADAN FASTING IN PATIENTS WITH OTHER DISEASES}

Among asthmatic patients, in a case-control study involving 15 asthmatic patients and 14 controls, fasting was shown to significantly decrease CRP levels. Pulmonary function tests levels post fasting were not shown to demonstrate any significant difference between both groups. Moreover, respiratory symptoms were not significantly increased. These results highlight the safety and lack of negative impact on asthma with some possible positive effects reflected by reduction of CRP levels (37).

In HIV patients on antiretroviral therapy, once-daily compared to twice daily dose therapy in fasting patients was not shown to lead to any significant changes in cluster differentiation 4 cell counts, viral load, or hematocrit levels (41).

In outpatient schizophrenic patients, a prospective study on 100 patients revealed that Ramadan fasting had a negative impact rather than a positive one on schizophrenic patients. This was reflected by a significant increase of lymphocytes, monocytes, fibrinogen and hs-CRP, especially in patients with metabolic syndrome. These results contrast with the many previously mentioned studies that reported the beneficial role of fasting on different inflammatory disease states (43).

\section{RAMADAN FASTING IN ATHLETES}

The behavioral fluctuation that occurs during Ramadan including food and drink abstinence is thought to impact athletes on intensive regimens. The influence of intermittent fasting (Ramadan model) on the inflammatory and immunologic measures of 15 elite male judo athletes was monitored. Serum CRP increased from $2.93 \pm 0.26$ to $4.60 \pm 0.51 \mathrm{mg} / \mathrm{L}$, IgA increased from $1.87 \pm 0.56$ to $2.49 \pm 0.75 \mathrm{~g} / \mathrm{L}$ and persisted high for 3 weeks. Hcy remained relatively unchanged, as well as leukocyte counts, which also remained stable through the examined period. Such results highlight the various yet minimal fluctuations of immunologic markers that might occur in athletes who maintain a high intensity training program during Ramadan (49). In another studies, recreational bodybuilders did not show any significant changes in CRP levels (47). Among rugby players, IgA levels were demonstrated to be elevated as shown in previous studies (45).

Other Ramadan-associated behavioral fluctuations include the change of sleep habits, which might disturbs athletes' physical performance. To study this effect, the performance of eight middle-distance athletes (average age of 25 years) was monitored 5 days before Ramadan, on the seventh day and on the 21st day of Ramadan fasting. Maximal aerobic velocity (MAV) test was performed on these days. Salivary cortisol, testosterone secretions and IL-6 levels, which play a role in sleep mediation, were measured. Compared with basal values, MAV test decreased significantly during Ramadan, while hormone levels did not show any significant deviations. Fatigue levels as measured by the Mood States questionnaire were also significantly increased, concomitant with a significant increase of IL-6, adrenaline and noradrenaline and a significant decrease of melatonin. Noteworthy, all these parameters trended back to normal ranges in 1 week after Ramadan. These finding supports the influence of Ramadan on athletes as witnessed by sleep disturbances, energy deficiency, and fatigue (27).

Strenuous exercise has been shown to influence myriad components of the immune system including neutrophils and natural killer (NK) cells. Interleukin 12 (IL-12), an immune-regulatory cytokine, is an avid NK cell activator as well an important inducer of pro-inflammatory factors secretion. During fasting, IL-12 was noted to be significantly decreased at 1 and 4 weeks in comparison to 3 weeks after Ramadan. The fluctuation of IL-12 levels has been attributed to changes in dietary intake as well as to sleep pattern alterations (48).

Intermittent exercise performed during Ramadan fasting has also been shown to enhance lipid profile and decrease inflammatory markers of cardiovascular health. In 15 healthy soccer players performing the yo-yo intermittent recovery test (YYIRT) during the evening hours while fasting, higher levels of high density lipoproteins and apolipoprotein A1 were documented, and a decrease of low density lipoprotein (LDL), apolipoprotein $\mathrm{B}$, lipoprotein particles, hcy and hs-CRP. Therefore, fasting and exercise work synergistically to reduce body mass, improve lipid profile, and modulate the inflammatory status in athletes (46). In another study, 20 male soccer players with a mean age of 17.5 years demonstrated an increase in TAS during YYIRT (44). In another study, the effect of Ramadan fasting on 79 soccer players aged 16-19 years showed a decrease in leukocyte count 


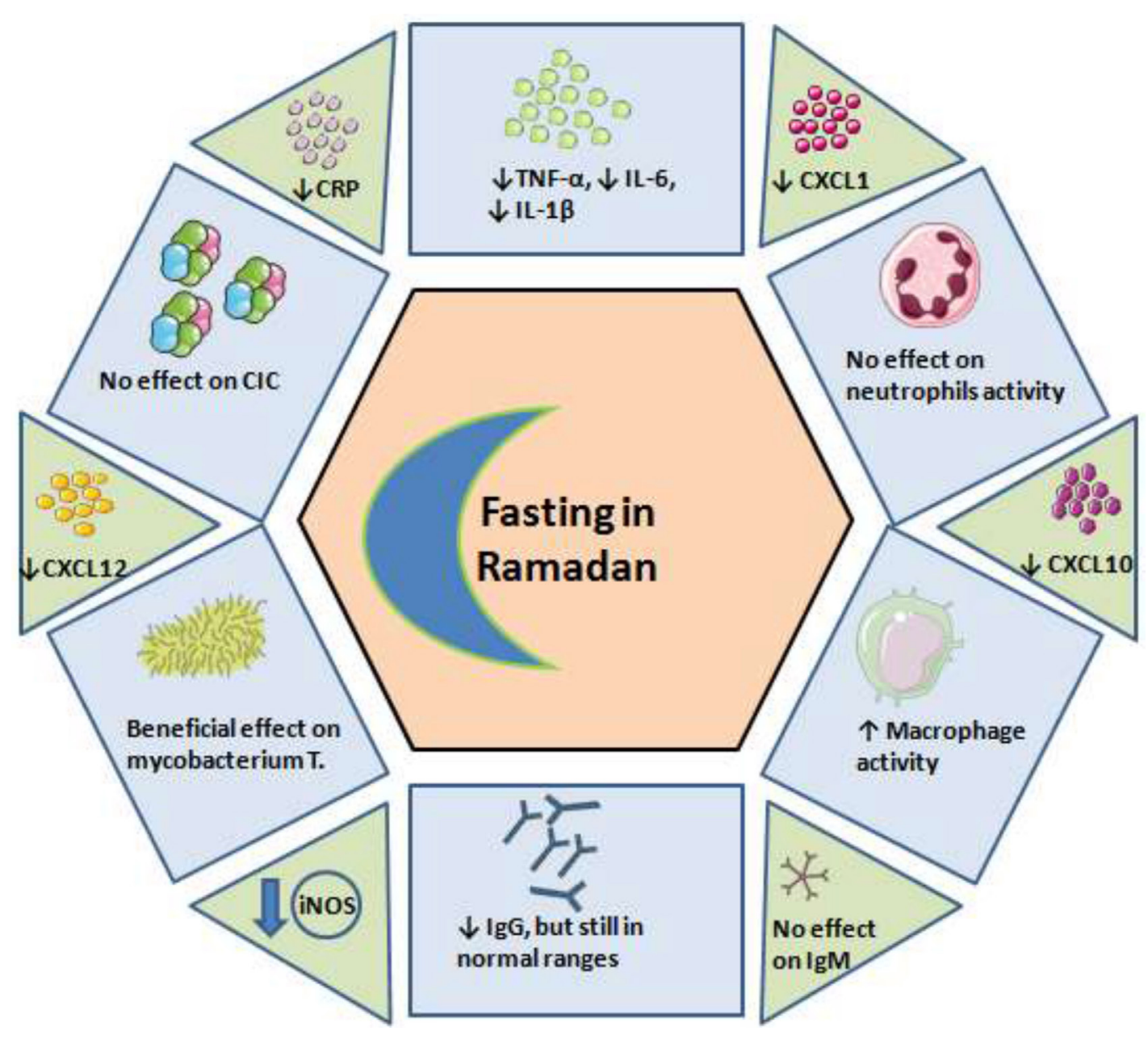

FIGURE 2 | The effect of fasting on the immune system. CIC, circulating immune complexes; CRP, C-reactive protein; CXCL, chemokines; iNOS, inducible nitric oxide synthases.

and CRP. These effects have been thought to occur as a result of eating habit changes (51).

\section{CONCLUSION}

Ramadan is observed by fasting in the Islamic communities; however, guidelines or consensus statements that help guiding physicians in addressing the issues of patients who are eager to fast are lacking. In this review, we aimed to systematically collect the current evidence concerning the influence of Ramadan fasting on the immune system. We can conclude that (Table 3; Figure 2):

1. Ramadan fasting has been shown to only mildly influence the immune system, and the alterations are transient and return to basal pre-Ramadan status.

2. Ramadan fasting during the second trimester of pregnancy was shown to be safe and did not result in negative fetal outcomes or maternal oxidative status alterations.
3. In cardiac patients, Ramadan fasting can have beneficial effects including lipid profile improvement and alleviation of oxidative stress.

4. In asthmatic patients, Ramadan fasting does not alter immunologic parameters.

5. In HIV patients, Ramadan was shown to be safe.

6. In patients with schizophrenia, Ramadan could increase immunologic markers.

7. In patients with autoimmune disorders, Ramadan was generally safe.

8. Fasting athletes who maintain intensive training schedule show fluctuations of immunologic markers.

\section{AUTHOR CONTRIBUTIONS}

NLB conceived and designed the study. MA, AW, NM wrote the manuscript. KA, HA, MZ, SB, KS, KG, RF, HM, SF, GSS critically revised the manuscript. All authors read and approved the final version of the manuscript. 


\section{REFERENCES}

1. Berbari AE, Daouk NA, Mallat SG, Jurjus AR. Ramadan fasting in health and disease. Special Issues in Hypertension. Milan: Springer Milan (2012). p. 1-483.

2. Al Wakeel J, Mitwalli AH, Alsuwaida A, Al Ghonaim M, Usama S, Hayat A, et al. Recommendations for fasting in Ramadan for patients on peritoneal dialysis. Perit Dial Int (2013) 33:86-91. doi:10.3747/pdi.2010.00095

3. Bragazzi NL, Watad A. The impact of fasting on rheumatic diseases. Isr Med Assoc J (2017) 19:378-9.

4. Razeghi Jahromi S, Ghaemi A, Alizadeh A, Sabetghadam F, Moradi Tabriz H, Togha M. Effects of intermittent fasting on experimental autoimune encephalomyelitis in C57BL/6 mice. Iran J Allergy Asthma Immunol (2016) 15:212-9.

5. Shawky S, Zaid A, Orabi S, Shogby K, Hassan W. Effect of intermittent fasting on brain neurotransmitters, neutrophils phagocytic activity, and histopathological finding in some organs in rats. Int J Res Stud Biosci (2015) 3:38-45.

6. Sadek K, Saleh E. Fasting ameliorates metabolism, immunity, and oxidative stress in carbon tetrachloride-intoxicated rats. Hum Exp Toxicol (2014) 33:1277-83. doi:10.1177/0960327114527629

7. Ajabnoor GMA, Bahijri S, Shaik NA, Borai A, Alamoudi AA, Al-Aama JY, et al. Ramadan fasting in Saudi Arabia is associated with altered expression of CLOCK, DUSP and IL-1alpha genes, as well as changes in cardiometabolic risk factors. PLoS One (2017) 12:e0174342. doi:10.1371/journal.pone. 0174342

8. Mohammadzade F, Vakili MA, Seyediniaki A, Amirkhanloo S, Farajolahi M, Akbari $\mathrm{H}$, et al. Effect of prolonged intermittent fasting in Ramadan on biochemical and inflammatory parameters of healthy men. J Clin Basic Res (JCBR) (2017) 1:38-46.

9. Nasiri J, Khoshdel A, Kheiri S, Jafari Boroujeni A. The effect of Ramadan fasting on tuberculin skin test and leukocyte count. J Fast Health (2017) 5:1-5.

10. BaHammam AS, Pandi-Perumal SR, Alzoghaibi MA. The effect of Ramadan intermittent fasting on lipid peroxidation in healthy young men while controlling for diet and sleep: a pilot study. Ann Thorac Med (2016) 11:43-8. doi:10.4103/1817-1737.172296

11. Bahijri SM, Ajabnoor GM, Borai A, Al-Aama JY, Chrousos GP. Effect of Ramadan fasting in Saudi Arabia on serum bone profile and immunoglobulins. Ther Adv Endocrinol Metab (2015) 6:223-32. doi:10.1177/2042018815594527

12. Delpazir S, Norouzy A, Mazidi M, Rezaie P, Moshiri M, Etemad L, et al. Effects of Ramadan fasting on oxidative stress and prooxidant-antioxidant balance: a short communication. J Fast Health (2015) 3:55-7.

13. Gorjipour K, Yeganeh F, Haji Molla Hoseini M. The effect of fasting on the functioning of the immune system based on the measurement of plasma granulysin level. J Res Religion Health (2015) 1(3):25-32.

14. Feizollahzadeh S, Rasuli J, Kheirouri S, Alizadeh M. Augmented plasma adiponectin after prolonged fasting during Ramadan in men. Health Promot Perspect (2014) 4:77-81. doi:10.5681/hpp.2014.010

15. Lahdimawan A, Handono K, Indra MR, Prawiro SR. Effect of Ramadan fasting on the ability of serum, PBMC and macrophages from healthy subjects to kill M. tuberculosis. IOSR J Pharm Biol Sci (2014) 9:24-9.

16. Akrami Mohajeri F, Ahmadi Z, Hassanshahi G, Akrami Mohajeri E, Ravari A, Ghalebi SR. Dose Ramadan fasting affects inflammatory responses: evidences for modulatory roles of this unique nutritional status via chemokine network. Iran J Basic Med Sci (2013) 16:1217-22.

17. Develioglu ON, Kucur M, Ipek HD, Celebi S, Can G, Kulekci M. Effects of Ramadan fasting on serum immunoglobulin $\mathrm{G}$ and $\mathrm{M}$, and salivary immunoglobulin A concentrations. J Int Med Res (2013) 41:463-72. doi:10.1177/ 0300060513476424

18. Lahdimawan A, Handono K, Indra MR, Prawiro SR. Effect of Ramadan fasting on endorphin and endocannabinoid level in serum, PBMC and macrophage. Int J Pharm Sci Invent (2013) 2(3):46-54.

19. Lahdimawan A, Handono K, Indra MR, Prawiro SR. Effect of Ramadan fasting on classically activated, oxidative stress and inflammation of macrophage. IOSR J Pharm (IOSRPHR) (2013) 3:14-22. doi:10.9790/3013-034101422

20. Faris MA-IE, Hussein RN, Al-Kurd RAA, Al-Fararjeh MA, Bustanji YK, Mohammad MK. Impact of Ramadan intermittent fasting on oxidative stress measured by urinary 15-F2t-isoprostane. J Nutr Metab (2012) 2012:1-9. doi:10.1155/2012/802924

21. Faris MA-IE, Kacimi S, Al-Kurd RAA, Fararjeh MA, Bustanji YK, Mohammad MK, et al. Intermittent fasting during Ramadan attenuates proinflammatory cytokines and immune cells in healthy subjects. Nutr Res (2012) 32:947-55. doi:10.1016/j.nutres.2012.06.021

22. Mohammed K, Mahmood M. Effect of Ramadan fasting on the levels of IL-1 $\alpha$, IL-2, IL-6 and IL-8 cytokines. Diyala J Pure Sci (2010) 6(4):308-13.

23. Sülü B, Öztürk B, Güven A, Kiliç K. The effect of long-term controlled fasting (the Ramadan model) on body mass index, blood biochemistry and oxidative stress factors. Turkiye Klinikleri J Med Sci (2010) 30:855-63. doi:10.5336/ medsci.2008-9981

24. Latifynia A, Vojgani M, Gharagozlou MJ, Sharifian R. Neutrophil function (innate immunity) during Ramadan. J Ayub Med Coll Abbottabad (2009) 21:111-5.

25. Ibrahim WH, Habib HM, Jarrar AH, Al Baz SA. Effect of Ramadan fasting on markers of oxidative stress and serum biochemical markers of cellular damage in healthy subjects. Ann Nutr Metab (2008) 53:175-81. doi:10.1159/ 000172979

26. Latifynia A, Vojgani M, Jafarieh H, Abofazeli T. Neutrophil respiratory burst (innate immunity) during Ramadan. J Biol Sci (2007) 7:997-1000. doi:10.3923/ jbs.2007.997.1000

27. Aksungar FB, Topkaya AE, Akyildiz M. Interleukin-6, C-reactive protein and biochemical parameters during prolonged intermittent fasting. Ann Nutr Metab (2007) 51:88-95. doi:10.1159/000100954

28. Latifynia A, Vojgani M, Abofazeli T, Jafarieh H. Circulating immune complex during Ramadan. J Ayub Med Coll Abbottabad (2007) 19:15-8.

29. Latifynia A, Vojgani M, Gharagozlou MJ, Sharifian R. Effect of Ramadan on neutrophil's respiratory burst (innate immunity) and circulating immune complex. J Ayub Med Coll Abbottabad (2008) 20:128-31.

30. Maliji GH, Dordi Q, Omran MS, Habibi T. Effects of Ramadan fasting on complement components activities $\mathrm{C} 3, \mathrm{C} 4$, and $\mathrm{CH} 50$ of human serum. J Ilam Univ Med Sci (2006) 14:50-4.

31. Asgary S, Aghaei F, Gholam N, Roya K, Mojfan G, Shiva A. Effects of Ramadan fasting on lipid peroxidation, serum lipoproteins and fasting blood sugar. Med J Islamic Acad Sci (2000) 13:35-8.

32. Goharifar H, Faezi ST, Paragomi P, Montazeri A, Banihashemi AT, Akhlaghkhah M, et al. The effect of Ramadan fasting on quiescent systemic lupus erythematosus (SLE) patients' disease activity, health quality of life and lipid profile: a pilot study. Rheumatol Int (2015) 35:1409-14. doi:10.1007/ s00296-015-3282-5

33. El-Dayem SMA, Zyton HAH. The effect of Ramadan fasting on multiple sclerosis. Egypt J Neurol Psychiatry Neurosurg (2012) 49:341-5.

34. Sharma M, Veena S, Gupta M, Tailang M, Pathak AK. Quantitative change in circulating immune complexes during Ramadan in rheumatoid arthritis patients. J Pharm Res (2011) 4(5):1306.

35. Saadatnia M, Etemadifar M, Fatehi F, Ashtari F, Shaygannejad V, Chitsaz A, et al. Short-term effects of prolonged fasting on multiple sclerosis. Eur Neurol (2009) 61:230-2. doi:10.1159/000197108

36. Tavakkoli H, Haghdani S, Emami MH, Adilipour H, Tavakkoli M, Tavakkoli M. Ramadan fasting and inflammatory bowel disease. Indian $J$ Gastroenterol (2008) 27:239-41.

37. Askari VR, Alavinezhad A, Boskabady MH. The impact of "Ramadan fasting period" on total and differential white blood cells, haematological indices, inflammatory biomarker, respiratory symptoms and pulmonary function tests of healthy and asthmatic patients. Allergol Immunopathol (Madr) (2016) 44:359-67. doi:10.1016/j.aller.2015.10.002

38. Al-Shafei AI. Ramadan fasting ameliorates oxidative stress and improves glycemic control and lipid profile in diabetic patients. Eur J Nutr (2014) 53:1475-81. doi:10.1007/s00394-014-0650-y

39. Khafaji HARH, Bener A, Osman M, Al Merri A, Al Suwaidi J. The impact of diurnal fasting during Ramadan on the lipid profile, hs-CRP, and serum leptin in stable cardiac patients. Vasc Health Risk Manage (2012) 8:7-14.

40. Nematy M, Alinezhad-Namaghi M, Rashed MM, Mozhdehifard M, Sajjadi SS, Akhlaghi S, et al. Effects of Ramadan fasting on cardiovascular risk factors: a prospective observational study. Nutr J (2012) 11:69. doi:10.1186/ 1475-2891-11-69 
41. Yakasai AM, Muhammad H, Babashani M, Jumare J, Abdulmumini M, Habib AG. Once-daily antiretroviral therapy among treatment-experienced Muslim patients fasting for the month of Ramadan. Trop Doct (2011) 41:233-5. doi:10.1258/td.2011.110130

42. Ozturk E, Balat O, Ugur MG, Yazıcioglu C, Pence S, Erel Ö, et al. Effect of Ramadan fasting on maternal oxidative stress during the second trimester: a preliminary study. J Obstet Gynaecol Res (2011) 37:729-33. doi:10.1111/j. 1447-0756.2010.01419.x

43. Fawzi MH, Fawzi MM, Said NS, Fawzi MM, Fouad AA, Abdel-Moety H. Effect of Ramadan fasting on anthropometric, metabolic, inflammatory and psychopathology status of Egyptian male patients with schizophrenia. Psychiatry Res (2015) 225:501-8. doi:10.1016/j.psychres.2014.11.057

44. Hammouda O, Chtourou H, Aloui A, Mejri MA, Chahed H, Miled A, et al. Does Ramadan fasting affect the diurnal variations in metabolic responses and total antioxidant capacity during exercise in young soccer players? Sport Sci Health (2014) 10:97-104. doi:10.1007/s11332-014-0179-8

45. Khazaei H, Bokaeian M, Jalili A. The effect of fasting on the immune system of athletes during holly Ramadan. Zahedan J Res Med Sci (2013) 16:44-6.

46. Hammouda O, Chtourou H, Aloui A, Chahed H, Kallel C, Miled A, et al. Concomitant effects of Ramadan fasting and time-of-day on apolipoprotein AI, B, Lp-a and homocysteine responses during aerobic exercise in Tunisian soccer players. PLoS One (2013) 8:e79873. doi:10.1371/journal.pone. 0079873

47. Trabelsi K, Stannard SR, Maughan RJ, Jammoussi K, Zeghal K, Hakim A. Effect of resistance training during Ramadan on body composition and markers of renal function, metabolism, inflammation, and immunity in recreational bodybuilders. Int J Sport Nutr Exerc Metab (2012) 22:267-75. doi:10.1123/ijsnem.22.4.267

48. Abedelmalek S, Souissi N, Takayuki A, Hadouk S, Tabka Z. Effect of acute maximal exercise on circulating levels of interleukin-12 during Ramadan fasting. Asian J Sports Med (2011) 2:154-60. doi:10.5812/asjsm.34751

49. Chaouachi A, Coutts AJ, Wong DP, Roky R, Mbazaa A, Amri M, et al. Haematological, inflammatory, and immunological responses in elite judo athletes maintaining high training loads during Ramadan. Appl Physiol Nutr Metab (2009) 34:907-15. doi:10.1139/H09-095

50. Chennaoui M, Desgorces F, Drogou C, Boudjemaa B, Tomaszewski A, Depiesse F, et al. Effects of Ramadan fasting on physical performance and metabolic, hormonal, and inflammatory parameters in middle-distance runners. Appl Physiol Nutr Metab (2009) 34:587-94. doi:10.1139/H09-014

51. Maughan RJ, Leiper JB, Bartagi Z, Zrifi R, Zerguini Y, Dvorak J. Effect of Ramadan fasting on some biochemical and haematological parameters in Tunisian youth soccer players undertaking their usual training and competition schedule. J Sports Sci (2008) 26:S39-46. doi:10.1080/02640410802491368

52. Choi IY, Lee C, Longo VD. Nutrition and fasting mimicking diets in the prevention and treatment of autoimmune diseases and immunosenescence. Mol Cell Endocrinol (2017) 455:4-12. doi:10.1016/j.mce.2017.01.042

53. Ugochukwu NH, Figgers CL. Caloric restriction inhibits up-regulation of inflammatory cytokines and TNF-alpha, and activates IL-10 and haptoglobin in the plasma of streptozotocin-induced diabetic rats. J Nutr Biochem (2007) 18:120-6. doi:10.1016/j.jnutbio.2006.03.008

54. Kafami L, Raza M, Razavi A, Mirshafiey A, Movahedian M, Khorramizadeh MR. Intermittent feeding attenuates clinical course of experimental autoimmune encephalomyelitis in C57BL/6 mice. Avicenna J Med Biotechnol (2010) 2:47-52.

Conflict of Interest Statement: The authors declare that the research was conducted in the absence of any commercial or financial relationships that could be construed as a potential conflict of interest.

Copyright (C) 2017 Adawi, Watad, Brown, Aazza, Aazza, Zouhir, Sharif, Ghanayem, Farah, Mahagna, Fiordoro, Sukkar, Bragazzi and Mahroum. This is an open-access article distributed under the terms of the Creative Commons Attribution License (CC $B Y)$. The use, distribution or reproduction in other forums is permitted, provided the original author(s) or licensor are credited and that the original publication in this journal is cited, in accordance with accepted academic practice. No use, distribution or reproduction is permitted which does not comply with these terms. 